\title{
DAMPAK PSIKOLOGI WANITA DAN ANAK-ANAK PADA KEKERASAN DALAM RUMAH TANGGA DI MASJID AL-HIDAYAH PAMULANG -TANGERANG SELATAN
}

\author{
Krisnaldy*, Jamaludin , Ela Hulasoh \\ Dosen Ekonomi Fakultas Ekonomi Universitas Pamulang \\ Email*: krisnaldyunpam@,gmail.com
}

\begin{abstract}
ABSTRAK
Pengabdian ini berjudul Dampak Psikologi Wanita Dan Anak-Anak Pada Kekerasan Dalam Rumah Tangga DiMasjid Al-Hidayah Pamulang,Tangerang Selatan.

Tujuan pengabdian ini adalah untuk Membantu memberikan arahan terhadap kepala keluarga, wanita ,dan anak-anak apa dampak dari kekerasan dalam rumah tangga dan Memberikan semangat dan motivasi bagi kepala keluarga,wanita dan anak anak dalam menjalani kehidupan yang lebih baik. Metode pelaksanaan pengabdian ini dilakukan dalam beberapa kegiatan yaitu tahap survei yaitu sosialisasi dilakukan dengan menyusun berbagai hal yang akan disampaikan pada saat kegiatan pengabdian yang akan dilakukan yang meliputi: penyusunan materi yang akan diberikan, penyusunan jadwal pemberian materi, pembagian tugas tim pengabdian dan survei ke lokasi pengabdian. Tahap sosialisasi yaitu sebelum kegiatan pengabdian dilaksanakan terlebih dahulu dilakukan tahap sosialisasi yaitu melakukan silaturahmi dengan ketua yayasan, menyampaikan maksud dan tujuan pengabdian ini. Pada tahap ini juga dilakukan jalinan kerjasama dan menentukan jadwal kegiatan pengabdian. Tim pelaksana kegiatan pengabdian pada masyarakat adalah dosen Fakultas Ekonomi jurusan manajemen sebanyak 11 orang. Tim pengabdian memberikan materi tentang Dampak Psikologi dan akibat dari Kekerasan rumah tangga di masjid Al-hidayah Pamulang, Tangerang Selatan dan akan memberikan pelatihan disana oleh dosen UNPAM dan bekerja sama dengan DPMP3AKB.

Kesimpulan dari pengabdian ini adalah Peserta kurang mengerti apa itu dampak psikologi wanita dan anak anak pada kekerasan dalam rumah tangga. Peserta juga belum mengetahui bagaimana cara menghadapi dilema pada kekerasan rumah tangga. Harapan kami dengan pengabdian ini dapat membuka wawasan masyarakat yang diperoleh adalah bertambahnya keilmuan bagi para Para Masyarakat tentang dampak psikologi wanita dan anak- anak pada kekerasan rumah tangga dan Ilmu yang diperoleh pada Pengabdian Masyarakat kali ini diharapkan
\end{abstract}


mampu memberikan semangat baru bagi kita dalam menyampaikan materi dan motivasi serta berkontribusi bagi generasi muda, baik dilingkungan sekolah, kampus dan keluarga

\section{Kata Kunci: Dampak Psikologi, Kekerasan Dalam Rumah Tangga}

\section{PENDAHULUAN}

KDRT adalah persoalan yang rumit untuk dipecahkan. Ada banyak alasan. Boleh jadi, pelaku KDRT benar-benar tidak menyadari bahwa apa yang telah ia lakukan adalah merupakan tindak KDRT. Atau, bisa jadi pula, pelaku menyadari bahwa perbuatan yang dilakukannya merupakan tindakan KDRT. Hanya saja, ia mengabaikannya lantaran berlindung diri di bawah norma-norma tertentu yang telah mapan dalam masyarakat. Sehingga menganggap perbuatan KDRT sebagai hal yang wajar dan pribadi

Definisi Kekerasan dalam Rumah Tangga atau KDRT, sebagaimana dikemukakan dalam Pasal 1 UU Nomor 23 tahun 2004 tentang Penghapusan Kekerasan dalam Rumah Tangga (UU PKDRT) adalah setiap perbuatan terhadap seseorang terutama perempuan, yang berakibat timbulnya kesengsaraan atau penderitaan secara fisik, seksual, psikologis, dan/atau penelantaran rumah tangga termasuk ancaman untuk melakukan perbuatan, pemaksaan, atau perampasan kemerdekaan secara melawan hukum dalam lingkup rumah tangga. UU PKDRT ini lahir melalui perjuangan panjang selama lebih kurang tujuh tahun yang dilakukan para aktivis gerakan perempuan dari berbagi elemen.

Di Indonesia, secara legal formal, ketentuan ini mulai diberlakukan sejak tahun 2004. Misi dari Undang-undang ini adalah sebagai upaya, ikhtiar bagi penghapusan KDRT. Dengan adanya ketentuan ini, berarti negara bisa berupaya mencegah terjadinya kekerasan dalam rumah tangga, menindak pelaku kekerasan dalam rumah tangga, dan melindungi korban akibat KDRT. Sesuatu hal yang sebelumnya tidak bisa terjadi, karena dianggap sebagai persoalan internal keluarga seseorang. Pasalnya, secara tegas dikatakan bahwa, tindakan keekerasan fisik, psikologis, seksual, dan penelantaran rumah tangga (penelantaran ekonomi) yang dilakukan dalam lingkup rumah tangga merupakan tindak pidana. Tindakantindakan tersebut mungkin biasa dan bisa terjadi antara pihak suami kepada isteri dan sebaliknya, atapun orang tua terhadap anaknya. Sebagai undang-undang yang membutuhkan pengaturan khusus, selain berisikan pengaturan sanksi pidana, undang-undang ini juga mengatur tentang hukum acara, kewajiban negara dalam memberikan perlindungan segera kepada korban yang melapor. Dengan demikian, bisa dikatakan bahwa ketentuan ini adalah sebuah terobosan hukum yang sangat 
penting bagi upaya penegakan HAM, khusunya perlindungan terhadap mereka yang selama ini dirugikan dalam sebuah tatanan keluarga atau rumah tangga.

Terobosan hukum lain yang juga penting dan dimuat di dalam UU PKDRT adalah identifikasi aktor-aktor yang memiliki potensi terlibat dalam kekerasan. Pada Pasal 2 UU PKDRT disebutkan bahwa lingkup rumah tangga meliputi (a) suami, isteri, dan anak, (b) orang-orang yang memiliki hubungan keluarga sebagaimana dimaksud pada huruf (a) karena hubungan darah, perkawinan, persusuan, pengasuhan, dan perwalian, yang menetap dalam rumah tangga dan atau (c) orang-orang yang bekerja membantu rumah tangga dan menetap dalam rumah tangga tersebut sehingga dipandang sebagai anggota keluarga. Identifikasi kekerasan terhadap pekerja rumah tangga sebagai kekerasan domestik sempat mengundang kontraversi karena ada yang berpendapat bahwa kasus tersebut hendaknya dilihat dalam kerangka relasi pekerjaan (antara pekerja dengan majikan). Meskipun demikian, UU PKDRT mengisi jurang perlindungan hukum karena sampai saat ini undang-undang perburuhan di Indonesia tidak mencakup pekerja rumah tangga. Sehingga korban kekerasan dalam rumah tangga adalah orang yang mengalami kekerasan dan/atau ancaman kekerasan dalam lingkup rumah tangga.

UU PKDRT merupakan terbosan hukum yang positif dalam ketatanegaraan Indonesia. Dimana persoalan pribadi telah masuk menjadi wilayah publik. Pada masa sebelum UU PKDRT ada, kasus-kasus KDRT sulit untuk diselesaikan secara hukum. Hukum Pidana Indonesia tidak mengenal KDRT, bahkan kata-kata kekerasan pun tidak ditemukan dalam Kitab Undang-Undang Hukum Pidana (KUHP). Kasus-kasus pemukulan suami terhadap isteri atau orang tua terhadap anak diselesaikan dengan menggunakan pasal-pasal tentang penganiayaan, yang kemudian sulit sekali dipenuhi unsur-unsur pembuktiannya, sehingga kasus yang diadukan, tidak lagi ditindaklanjuti.

Kecenderungan meningkatnya kasus KDRT yang dilaporkan ini menunjukkan adanya bangunan kesadaran masyarakat tentang kekerasan khusunya kekerasan yang terjadi di ranah rumah tangga pada umumnya dan kesadaran serta keberanian perempuan korban untuk melaporkan kasus KDRT yang dialaminya,pada khususnya.

Banyaknya kasus yang dalam perjalannnya dicabut oleh pelapor yang sekaligus juga korban, lebih karena banyaknya beban gender perempuam korban yang seringkali harus ditanggung sendiri,, kuatnya budaya patriarkhi, doktrin agama, dan adat menempatkan perempuan korban kekerasan dalam rumah tangga dalam situasi yang sulit untuk keluar dari lingkar kekerasan yang dialaminya, dan cenderung ragu untuk mengungkap fakta kekerasannya, bahkan korban sulit 
mendapat dukungan dari keluarga maupun komunitas. Keyakinan 'berdosa' jika menceritakan 'kejelekan, keburukan, atau aib' suami membuat banyak perempuan korban kekerasan dalam rumah tangga menyimpan dalam-dalam berbagai bentuk kekerasan yang dialaminya.

Dengan adanya materi ini tentang dampak psikologi wanita dan anak- anak pada kekerasan rumah tangga, Para pemikiran Kepala keluarga menjadi terbuka dan mampu mengatur arah hidup mereka secara mandiri dan bermanfaat untuk orang lain. Oleh karena itu ,Perlu adanya dukungan dan pihak Yayasan untuk menjalankan pelatihan ini agar tersampaikan dengan maksimal

\section{RUMUSAN MASALAH}

Dengan mempertimbangkan latar belakang yang telah diutarakan diatas kami berinisiatif untuk membentuk pengabdian masyarakat bagi kepala keluarga ,wanita dan anak anak melalui progam penyuluhan materi dampak psikologi wanita dan anak- anak pada kekerasan rumah tangga di masjid Alhidayah Pamulang oleh UNPAM dan DPMP3AKB yang beralamatkan Jl.Matoa I No.20 Pamulang.Tangerang Selatan. 15417. dengan bekerja sama dengan DPMP3AKB.Membekali keluarga, wanita dan anak-anak untuk hidup dalam lingkungan yang sehat dan beradap.

\section{TUJUAN PELAKSANAAN}

1. Membantu memberikan arahan terhadap kepala keluarga, wanita ,dan anak-anak apa dampak dari kekerasan dalam rumah tangga .

2. Memberikan semangat dan motivasi bagi kepala keluarga,wanita dan anak anak dalam menjalani kehidupan yang lebih baik

\section{TINJAUAN PUSTAKA}

\section{Pengertian Manajemen}

Pengertian manajemen secara umum dapat disimpulkan dari beberapa definisi menurut para ahli. Hal ini karena ada banyak versi definisi manajemen. Misalnya saja manajemen menurut seorang ahli bernama Mary Parker Follet yang mendefinisikan manajemen sebagai seni merampungkan pekerjaan melalui orang lain. Dari definisi tersebut didapati bahwa seseorang yang bertugas sebagai manajer dapat mengarahkan dan mengatur orang lain guna mencapai tujuan organisasi.

Di sisi lain, James A.F Stoner mendefinisikan manajemen sebagai proses pengorganisasian, perencanaan, dan penggunaan SDM supaya mencapai tujuan organisasi yang sudah ditetapkan. 
Secara umum, pengertian manajemen merupakan suatu seni dalam ilmu dan pengorganisasian seperti menyusun perencanaan, membangun organisasi dan pengorganisasiannya, pergerakan, serta pengendalian atau pengawasan. Bisa juga diartikan bahwa manajemen merupakan suatu ilmu pengetahuan yang sistematis agar dapat memahami mengapa dan bagaimana manusia saling bekerja sama agar dapat menghasilkan sesuatu yang bermanfaat bagi orang lain maupun golongan tertentu dan masyarakat luas.

Secara etimologis, pengertian manajemen merupakan seni untuk melaksanakan dan mengatur. Manajemen ini juga dilihat sebagai ilmu yang mengajarkan proses mendapatkan tujuan dalam organisasi, sebagai usaha bersama dengan beberapa orang dalam organisasi tersebut. Sehingga, ada orang yang merumuskan dan melaksanakan tindakan manajemen yang disebut dengan manajer.

\section{FUNGSI MANAJEMEN}

Pada dasarnya, fungsi manajemen dibagi menjadi tiga, yaitu:

\section{Perencanaan (planning)}

Pernecanaan adalah memikirkan apa yang akan dikerjakan dengan sumber yang dimiliki. Perencanaan dilakukan untuk menentukan tujuan perusahaan secara keseluruhan dan cara terbaik untuk memenuhi tujuan itu. Manajer mengevaluasi berbagai rencana alternatif sebelum mengambil tindakan dan kemudian melihat apakah rencana yang dipilih cocok dan dapat digunakan untuk memenuhi tujuan perusahaan. Perencanaan merupakan proses terpenting dari semua fungsi manajemen karena tanpa perencanaan, fungsi-fungsi lainnya tak dapat berjalan.

2. Pengorganisasian (organizing)

Pengorganisasian dilakukan dengan tujuan membagi suatu kegiatan besar menjadi kegiatan-kegiatan yang lebih kecil. Pengorganisasian mempermudah manajer dalam melakukan pengawasan dan menentukan orang yang dibutuhkan untuk melaksanakan tugas-tugas yang telah dibagi-bagi tersebut. Pengorganisasian dapat dilakukan dengan cara menentukan tugas apa yang harus dikerjakan, siapa yang harus mengerjakannya, bagaimana tugas-tugas tersebut dikelompokkan, siapa yang bertanggung jawab atas tugas tersebut, dan pada tingkatan mana keputusan harus diambil.

\section{Pengarahan (directing)}

Pengarahan adalah suatu tindakan untuk mengusahakan agar semua anggota kelompok berusaha agar dapat mencapai sasaran sesuai dengan perencanaan manajerial dan usaha.

\section{UNSUR-UNSUR MANAJEMEN}


Setiap perusahaan memiliki unsur-unsur untuk membentuk sistem manajerial yang baik. Unsur-unsur inilah yang disebut unsur manajemen. Jika salah satu diantaranya tidak sempurna atau tidak ada, maka akan berimbas dengan berkurangnya upaya untuk mencapai

\section{Pengertian Manajemen Sumber Daya Manusia}

Manajemen adalah ilmu dan seni yang megatur proses pemanfaatan sumber daya manusia dan sumber-sumber daya lainya secara efektif dan efesien untuk mencapai suatu tujuan tertentu.

Manajemen sumber daya manusia merupakan bagian dari ilmu manajemen yang memfokuskan perhatianya pada pengaturan peranan sumber daya manusia dalam kegiatan organisasi. Hal ini dikarnakan dalam mencapai tujuanya, organisasi memerlukan sumber daya manusia sebagai pengeelola sistemnya, dan agar sistem ini berjalan, dalam pengelolaanya diperlukan beberapa aspek penting, seprti pelatihan, pengembangan, motivasi dan aspek-aspek lainya. Hal ini yang menjadikan manajeman sumber daya manusia sebagai salah satu indikator penting pencapaian tujuan organisasi secara efektif dan efisien.( mila badriah, S.E.,M.M, 15: 2015).

Manusia selalu berperan aktif dan dominan dalam kegiatan organisasi karena manusia menjadi perencana, pelaku, dan penentu terwujudanya tujuan organisasi. Tujuan tidak mungkin terwujud tanpa peran aktif tanpa peran karyawan meskipun alat-alat yang dimiliki oleh perusahaan begitu canggih. Alat-alat canggih perusahaan tidak ada manfaatnya bagi perusahaan, jika peran aktif karyawan tidak di ikut sertakan. Mengatur karyawan merupakan hal yang sulit dan kompleks karena mereka mempunyai pikiran, perasaan, status, keinginan, dan latar belakang yang heterogen yang dibawa kedalam suatu organisasi. Karyawan tidak dapat di atur dan dikuasai sepenuhnya seperti mengatur mesin, moda, dan gedung.

Manajemen sumber daya manusia merupakan bagian dari manajemen. Oleh karna itu, teori-teori manajemen umum manjadi dasar pembahasaannya mengenai pengaturan peranaan manusia dalam menentukan tujuan yang optimal.

Pengaturan itu meliputi masalah perencanaan (human resources planning), pengorganisasian,pengarahaan,kompenasasi,pengintregrasian,pemeliharaan,kedisi plinan dan pemberhentian tenaga kerja untuk membantu terwujudnya tujuan perusahaan, karyawan, dan masyarakat.

Pengertian manajeman sumber daya manusia menurut malyu S.P. hasibuan ( 2005: 10 ) yang menyatakan bahwa : 
"manajeman sumber daya manusia adalah ilmu dan seni yang mengatur hubungan dan peranan tenaga kerja yang efektif dan efisien membantu terwujudnya tujuan perusahaan, karyawan, dan masyarakat".

\section{METODE PELAKSANAAN}

Metode pelaksanaan pengabdian ini dilakukan dalam beberapa kegiatan yaitu tahap survei yaitu sosialisasi dilakukan dengan menyusun berbagai hal yang akan disampaikan pada saat kegiatan pengabdian yang akan dilakukan yang meliputi: penyusunan materi yang akan diberikan, penyusunan jadwal pemberian materi, pembagian tugas tim pengabdian dan survei ke lokasi pengabdian. Tahap sosialisasi yaitu sebelum kegiatan pengabdian dilaksanakan terlebih dahulu dilakukan tahap sosialisasi yaitu melakukan silaturahmi dengan ketua yayasan, menyampaikan maksud dan tujuan pengabdian ini. Pada tahap ini juga dilakukan jalinan kerjasama dan menentukan jadwal kegiatan pengabdian. Tim pelaksana kegiatan pengabdian pada masyarakat adalah dosen Fakultas Ekonomi jurusan manajemen sebanyak 11 orang. Tim pengabdian memberikan materi tentang Dampak Psikologi dan akibat dari Kekerasan rumah tangga di masjid Al-hidayah Pamulang, Tangerang Selatan dan akan memberikan pelatihan disana oleh dosen UNPAM dan bekerja sama dengan DPMP3AKB.

\section{HASIL DAN PEMBAHASAN}

Pengabdian Masyarakat (LPPM) Universitas Pamulang yang dilakukan oleh dosen-dosen program studi Manajemen telah berjalan dengan lancar dan mendapat sambutan hangat dari tempat pelaksanaan kegiatan ini yaitu di Masjid AlHidayah Pamulang, Tangerang Selatan .

Harapan kami dengan pengabdian ini dapat membuka wawasan masyarakat yang diperoleh adalah bertambahnya keilmuan bagi para Para Masyarakat tentang dampak psikologi wanita dan anak- anak pada kekerasan rumah tangga dan Ilmu yang diperoleh pada Pengabdian Masyarakat kali ini diharapkan mampu memberikan semangat baru bagi kita dalam menyampaikan materi dan motivasi serta berkontribusi bagi generasi muda, baik dilingkungan sekolah, kampus dan keluarga.

\section{KESIMPULAN DAN SARAN}

Kesimpulan

Peserta kurang mengerti apa itu dampak psikologi wanita dan anak anak pada kekerasan dalam rumah tangga. Peserta juga belum mengetahui bagaimana cara menghadapi dilema pada kekerasan rumah tangga.

Saran 
Setelah pengabdian ini diharapkan peserta dapat memiliki hidup yang lebih sehat secara rohani dan membangun keluarga yang lebih harmonis serta mengajak teman/peserta lainnya untuk ikut menjadi relawan dalam memberantas tindak kekerasan terhadap wanita dan anak-anak. Tim pengabdian agar terus melakukan kegiatan-kegiatan serupa secara berkesinambungan di masa yang akan datang

\section{DAFTAR PUSTAKA}

Pasal 1 UU Nomor 23 tahun 2004 tentang Penghapusan Kekerasan dalam Rumah Tangga (UU PKDRT

Pada Pasal 2 UU PKDRT disebutkan bahwa lingkup rumah tangga meliputi (a) suami, isteri, dan anak, (b) orang-orang yang memiliki hubungan keluarga sebagaimana dimaksud pada huruf (a) karena hubungan darah, perkawinan, persusuan, pengasuhan, dan perwalian, yang menetap dalam rumah tangga dan atau (c) orang-orang yang bekerja membantu rumah tangga dan menetap dalam rumah tangga tersebut sehingga dipandang sebagai anggota keluarga

Arikunto, Suharsimi. 2008. Dasar-Dasar Evaluasi Pembelajaran. Jakarta: Bumi Aksara. $308 \mathrm{hlmn}$.

Kartini Kartono, 2008, Pemimpin dan kepemimpinan. Jakarta: Raja Grafindo Persada

\section{DOKUMENTASI FOTO KEGIATAN}

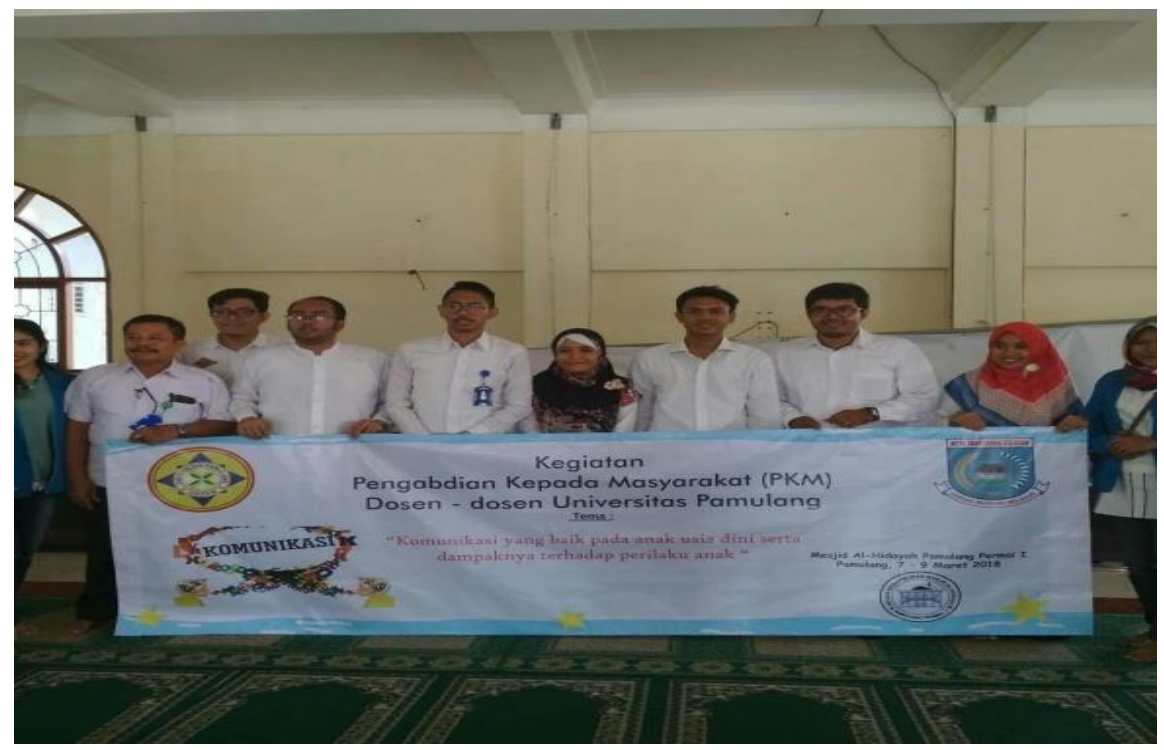



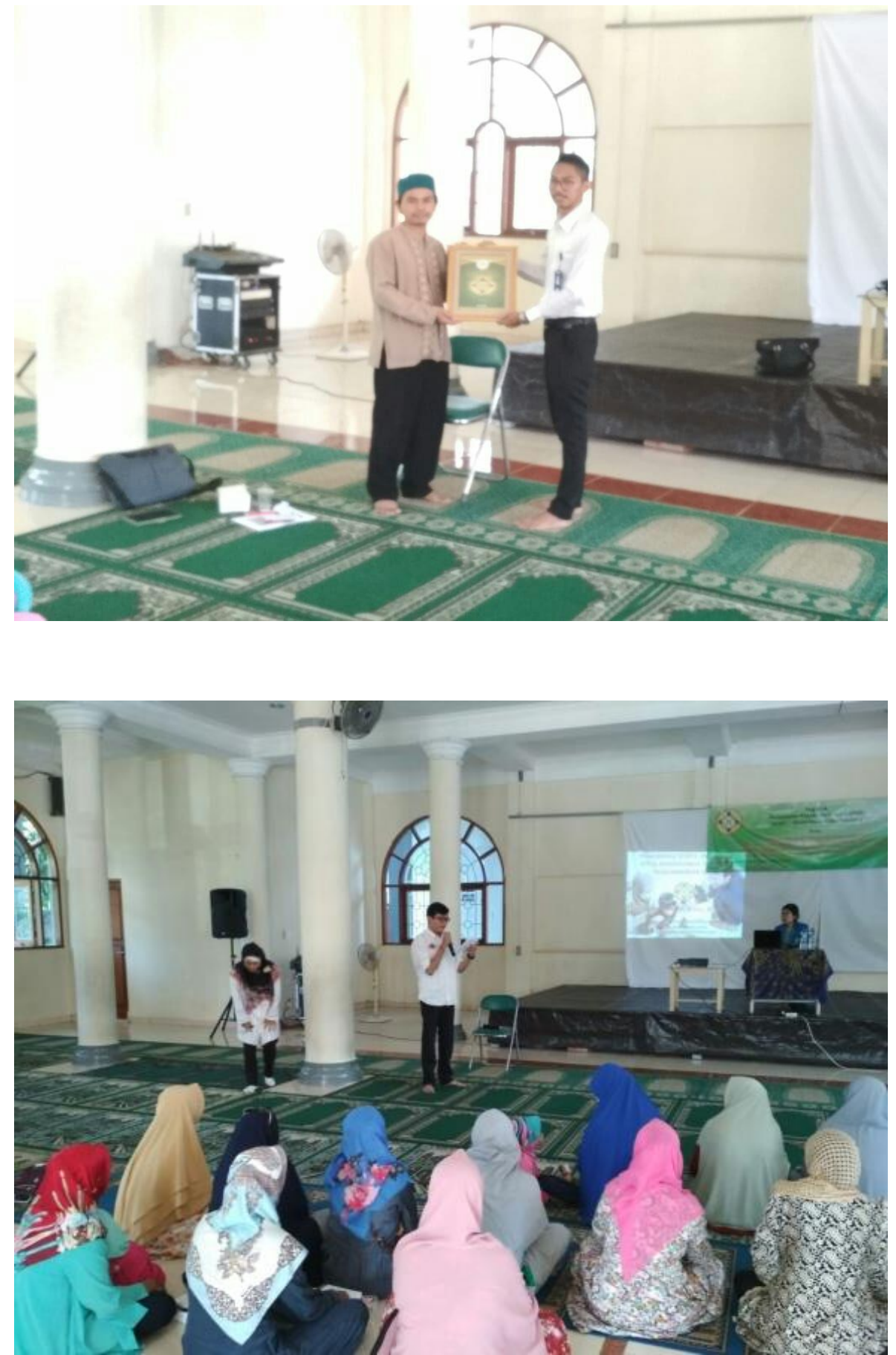